Москаленко О.Д. ORCID ID: 0000-0002-8577-1159

Зозульов О.В. канд. економ. наук, професор ORCID ID: 0000-0001-7087-2080

Національний технічний університет Украӥни «Київський політехнічний інститут імені Ігоря Сікорського»

\title{
ОСОБЛИВОСТІ НЕЙРОМАРКЕТИНГУ ТА АКТУАЛЬНІСТЬ ВИКОРИСТАННЯ АЙТРЕКІНГУ ПРИ ТЕСТУВАННІ ВЕБ-СТОРІНОК
}

\section{NEUROMARKETING FEATURES AND RELEVANCE OF USE OF WEBSITE TESTING BY EYES-TRACKING}

Необхідність маркетингових досліджень обумовлена потребою зниження ризику прийняття неправильного рішення за рахунок кращого знання і розуміння стану $і$ динаміки факторів навколишнього середовища. В даний час все більше компаній використовують новий напрямок маркетингових досліджень, який об'єднує в собі маркетинг, нейрофізіологію $i$ когнітивну психологію. У статті було комплексно розглянуто цей напрямок нейромаркетинг та досліджено використання одного з його інструментів - айтрекеру при тестуванні веб-сторінок. Стаття описує основні поняття, які лягли в основу нейромаркетингових досліджень. У роботі виділено $i$ охарактеризовано основні етапи нейромаркетингового дослідження. Стаття торкається питань, пов'язаних зі спеиіальними нейромаркетинговими інструментами, які маркетологи використовують для отримання актуальних результатів в ході досліджень. Також, виявлено основні причини використання спеціалізованих інструментів і визначені показники, які дослідники аналізують при формуванні висновків і рекомендацій для замовників. Авторами було описано показники, які $є$ універсальними для усіх інструментів нейромаркетингу. У статті подані результати дослідження з приводу використання технології айтрекінгу при тестуванні веб-сторінок. Визначено, що айтрекінг доповнює традииійні методи дослідження, дає нове розуміння проблеми $і$ наочно підтверджує сформовані гіпотези. У ході аналізу визначено, щзо результати дослідження за допомогою айтрекера містять як показники, так $i$ візуальні карти, що допомагає більш чітко відповісти на питання дослідження та сформувати рекомендації. Було виявлено $і$ зазначено у статті, щуо показники при тестуванні веб-сайтів за допомогою айтрекінгу необхідно розглядати у взаємозв'язку та зіставлені з критеріями оцінки Інтернет комунікацій. Авторами обтрунтовано актуальність використання технології компаніями, що займаються розробкою та тестуванням веб-сайтів, за допомогою зіставлення показників, які отримуються у проиесі нейромаркетингового дослідження та критеріїв ефективності маркетингових Інтернет-комунікаиій.

Ключові слова: маркетингове дослідження, нейромаркетинг, інструменти нейромаркетингу, етапи проведення нейромаркетингового дослідження, айтрекінг, айтрекер.

The need for marketing research is due to the need to reduce the risk of making the wrong decision at the expense of better knowledge and understanding of the state and dynamics of 
environmental factors. Currently, more and more companies are using a new area of marketing research, which combines marketing, neurophysiology and cognitive psychology. This direction neuro marketing was considered in a comprehensive manner. Moreover, the authors described using of one of neuro marketing's tools - eye tracker during the testing of web pages. The article describes the basic concepts that formed the basis of neuromarketing research. The paper identifies and describes the main stages of neuro marketing research. The article deals with issues related to special neuromarketing tools that marketers use to obtain relevant results in the course of research. Also, the main reasons for using neuro marketing tools are identified and the parameters identified by researchers are analysed in the formulation of conclusions and recommendations for clients. The authors described the indicators that are universal for all neuromarketing tools. The article presents the results of research on the use of eye tracking technology when testing web pages. It is determined that tracking eyes supplements traditional methods of research, gives a new understanding of the problem and clearly confirms the formed hypotheses. During process of analyse the authors found that the results of the research when marketer using the eye tracker contain both indicators and visual maps, which helps to more clearly answer on the research questions and formulate recommendations. It was discovered and stated in the article that the indicators for quality testing websites with eye tracker should be considered in a relationship and compared with the criteria for assessing Internet communications. The authors substantiated the urgency of using technology by companies involved in the development and testing of websites, by comparing the indicators obtained in the process of neuromarketing research and the criteria for the effectiveness of marketing Internet-communications.

Keywords: marketing research, neuro marketing, neuro marketing tools, stages of neuro marketing research, eye tracking, eye tracker

Вступ. Дослідження в області людської нейропсихології є надзвичайно важливими для прогнозування поведінки споживачів, що $\epsilon$ вирішальним фактором саме у маркетинговій діяльності. Можливість вивчення, дослідження та аналізу споживчої поведінки дають великі можливості для ефективної роботи спеціалістів по маркетингу. Тому, поєднання психологічних наук, нейро-наук i маркетингу може дати плідні результати. Таке поєднання втілилося у нейромаркетинг. Такий напрямок, як нейромаркетинг почали розглядати на початку ХХ століття такі науковці, як Дж. Залтмен, У. Скот та В. Вундт. На сьогоднішній день сутність наукових та практичних засад розглядаються такими науковцями, як О.Д. Бойко, А.А. Копейко, Е.Ю. Кан та інші. Варто зазначити, що значна кількість матеріалів публіцистичного характеру на цю тему існує в мережі інтернет, проте існують сумніви $з$ приводу достовірності такої інформації, а також відчувається нестача фундаментальних праць. Не дивлячись на те, що поняття «нейромаркетинг» 3’явилося нещодавно, на його основі було проведено вже багато досліджень, результати яких дозволяють отримати об'єктивну інформацію та вирішувати на основі неї маркетингові управлінські проблеми. Під час дослідження інструментів нейромаркетингу варто звернути увагу на айтрекінг, ця технологія дозволяє 
відстежувати рух погляду респондента. Результати використання такого інструменту нейромаркетингу, як айтрекер, затребуване у різних сферах, а особливо при тестуванні веб-сторінок. Інструмент застосовується для розробки якісних користувальницьких інтерфейсів, підвищення зручності і простоти користування ресурсом, підвищення конверсіі, вивчення користувацького досвіду. Тому, на нашу думку, в епоху цифрового маркетингу, нейромаркетингові дослідження з використанням айтрекера потребують більш глибокого дослідження.

Постановка завдання. Метою даної статті $є$ визначення особливостей використання інструменту нейромаркетингу - айтрекеру, необхідно обгрунтувати його доцільність при тестуванні веб-сторінок, визначити його основні показники i продемонструвати їх зв’язок 3 критеріями оцінки ефективності маркетингових Інтернет-комунікацій.

Методологія. Інформаційною базою даної роботи стали теоретичні напрацювання вчених, що досліджували нейромаркетинг, тематичні сайти, результати проведених нейромаркетингових досліджень, які були представлені компаніями-замовниками, матеріали зарубіжних конференцій. При проведенні дослідження використовувалися такі загальнонаукові методи: аналіз та синтез, системний аналіз, узагальнення. Теоретичним підгрунтям роботи стала теорія маркетингу, когнітивної психології та нейробіології.

Результати дослідження. Концепція нейромаркетингу з'явилась в 1990-ті роки в Гарвардському університеті, в результаті поєднання науки про людський мозок та економіку. В основі даної концепції лежать дослідження психологів, відповідно до яких біля 90 процентів всієї пізнавальної діяльності і всього мислення, включи емоції, відбувається у підсвідомості [5]. Тому, основне завдання, яке ставлять собі психологи від маркетингу - це вивчення підсвідомості споживачів.

Таким чином, можна зазначити, що нейромаркетинг - це новітній комплекс нейроприйомів, нейрометодів та нейротехнологій, який допомагає встановлювати комунікаційний зв'язок між компанією та споживчою аудиторією на рівні підсвідомості та активізувати купівлю товарів та послуг.

Вудвуд В.В. та Білоус А.Я. виділяють три основні підходи впливу нейромаркетингу на підсвідомість споживачів:

- аромамаркетинг - вплив за допомогою аромату;

- мерчандайзинг - вплив за допомогою кольору, зображень, розміщення;

- аудіомаркетинг - вплив за допомогою звуку.

Застосування всіх трьох елементів вважається потужним механізмом, який здатен буде вдвічі активізувати купівельну спроможність споживачів. 
Згідно наукових праць Вудвуда В.В., основні засади нейромаркетингу грунтуються на таких засадах:

- людина ірраціональна істота;

- людина не завжди говорить правду і це не означає, що людина обманює, просто вона не завжди може правильно висловлювати свої думки;

- людина не завжди може точно пояснити чому вона знає ті чи інші речі (прихована пам'ять - неусвідомлений минулий досвід);

- підсвідомість має могутню силу, іiі можна вивчати за допомогою цифр;

- автоматичний розум (більшість реакцій людини автоматичні) [1].

На сьогодні доведено, що підсвідомість людини є первинною і здійснює вплив на свідомість. А завдяки технологіям, які дозволяють встановити, як проходить обробка збудника в мозку, можна досягти максимально точного уявлення про нейрологічні процеси і пов'язані з ними когнітивні і емоційні можливості.

Оскільки ринок стає конкурентним, маркетологам потрібна краща інформація про споживчі потреби, бажання, реакцію на поведінку, використання медіа тощо. У результаті, спеціалісти прагнуть використовувати високотехнологічні розробки в своїй діяльності. Технічні компанії втілюють нові технології в битві за частку ринку. Одним 3 цих сучасних методів $\epsilon$ нейромаркетинг. Це неврологічне дослідження психічного стану та реакцій людини під час отримання маркетингових повідомлень. Загальна мета цього дослідження - зрозуміти світ нейромаркетингу як нову сферу маркетингу для кращого розуміння споживача.

Основні положення нейромаркетингу засновуються на тому, що необхідно передивитися погляди на маркетингове дослідження та сфокусуватися на вивченні людського сприйняття, досліджувати свідоме та несвідоме в людині.

Якщо говорити про нейромаркетинг, як про один 3 напрямів маркетингового дослідження, то головним об'єктом при його проведенні $\epsilon$ мозкова діяльність респондента, його емоційна залученість, увага, погляд, пульс, провідність шкіри, дихання.

Основна проблема визнання досліджень нейромаркетингу як методу дослідження полягає у неможливості винести практичні висновки 3 дослідження ( реалістичне розуміння ).

Для повного розуміння процесу проведення маркетинговою компанією нейромаркетингового дослідження, розглянемо послідовність його проведення:

1. Замовник формулює завдання. Це може бути, наприклад, просування бренду або створення рекламного ролику. 
2. Формування метаметодики маркетинговою дослідження: методики дослідження явища або процесу, методики здору даних та методики аналізу та інтерпретації даних.

3. Затвердження методики проведення маркетингового дослідження у замовника та укладання договору.

4. Відбір респондентів. Для цього зарубіжні нейромаркетиногові компанії дають рекрутинговим агентствам опис цільової аудиторії $\mathrm{i}$ вони здійснюють відбір респондентів для дослідження.

5. Респондентів запрошують в лабораторію для дослідженя.

6. 3 використанням спеціального обладнання реєструють нейрофізіологічні параметри респондента.

7. Інтерпретація отриманих даних.

8. Формування звіту з рекомендаціями.

Як ми бачимо, етапи проведення нейромаркетингового дослідження відрізняються від традиційних досліджень. Різниця полягає в тому, що у нейромаркетингових дослідженнях витрачається менше часу на підготовку до збору даних та використовується нейромаркетингове обладнання. Таку ситуацію можна пояснити тим, що традиційне маркетингове дослідження на сьогоднішній день має більш широкий арсенал методів проведення дослідження. А в нейромаркетинговому дослідженні, наявність того чи іншого обладнання для нього визначає хід дослідження.

Варто описати інструменти, які використовуються під час дослідження:

- Айтрекер реєструє рухи очей i відстежує координати погляду. Їх використовують для дослідження уваги та інтересу респондентів. Ідеально підходить для вимірювання ефективності веб-сайтів, рекламних роликів, кіно, відеоігор, рекламних матеріалів, дизайну логотипів, дизайну продукту, розміщення продукту на полиці тощо. Завдяки спостереженню за очима маркетологи зможуть перехопити реакцію людини, перш ніж вона зможе відфільтрувати іï та представити іiі вам спотворено або суб'єктивно. Цей інструмент дає можливість знати з високою ступенем визначеності, що бачать люди, і чого вони не бачать.

- Камера високого дозволу допомагає аналізувати мікроміміку для визначення емоцій (подив, страх, роздратування, радості й інших емоцій). Веб-камера робить 6 кадрів в секунду, що дозволяє зафіксувати найменшу зміну емоцій учасника, який сидить перед комп'ютером.

- Поліграф («детектор брехні») застосовується для реєстрації дихання, показників серцево-судинної активності, електричного опору шкіри. Поліграф використовують для оцінки емоційної залученості та переживань. 
- Електроенцефалограф реєструє біоелектричну активність мозку. Він дозволяє виявити широкий діапазон мозкових хвиль при проведенні тестів 3 досить високим рівнем точності. Ідеально підходить для вимірювання ефективності веб-сайтів, рекламних роликів, фільмів, відеоігор, рекламних матеріалів, дизайну продукту тощо.

- Функціонально магнітно-резонансна томографія допомагає стежити, які частини мозку активні, через процес збільшення кровотоку у них. Функціональна магнітно-резонансна томографія дозволяє відстежувати характер активності глибоких структур головного мозку (а не тільки кори головного мозку), які відповідають за емоційні прояви. Це дозволяє маркетологам отримати доступ до найглибшої частини мозку і дозволяє їм дізнатись, як люди дійсно реагують на певну тему [7].

Але, проведення комплексного нейромаркетингового дослідження передбачає глибинний аналіз даних. Тому, необхідно виявити показники, які будуть уніфікованими для інструментів нейромаркетингу і будуть повністю давати відповідь на ціль дослідження. Виокремимо показники оцінки результатів нейромаркетингового дослідження:

- показники уваги (реакція, пов'язана 3 виборчим сприйняттям елементів об'єкта, спрямована на сканування інформації і фокусування на значущих деталях);

- інтересу (пізнавальна потреба ознайомлення 3 тим, що відбувається, безпосередня зацікавленість візуальною інформацією);

- запам'ятовування (ймовірність запам'ятовування стимулу);

- емоційного залучення (короткочасна та довгострокова активність, що виражає емоційну реакцію у відповідь на пред'явлення стимулу).

Під час дослідження було прийнято рішення детально проаналізувати можливості та особливості використання такої технології нейромаркетингу, як айтрекінг. Метод оснований на записі руху зіниці ока. Айтрекер реєструє фіксацію зору (визначає координати затримки зору в певній точці, тривалість такої фіксації), переміщення погляду та його характер, траєкторію зміни погляду респондента.

Технологія айтрекінгу користується попитом серед компаній та підприємств, які проводять тестування веб-сторінок. Одним 3 основних показників Інтернет-комунікацій - $€$ ROI (return on investment), на який впливає дохід від реклами, кількість продажів та витрати на рекламу та сайт. Розробники веб-сайтів прагнуть підвищити цей показник і витрачають великі кошти на розробку дизайну сайту, роблять гарні фотографії товарів, створюють дійсно унікальні торгові пропозиції, але продажі не ростуть. Спеціалісти починають шукати проблему і проводять аналіз за допомогою систем вебаналітики (Яндекс.Метрика, Google Analytics тощо) i з'ясовують, що 
користувачі проводять деякий час на головній сторінці та йдуть. I тоді, актуалізується потреба в такій технології, як айтрекінг. Так, як причина відсутності продажів банальна - користувачі не бачать вигідних пропозицій, не помічають їх. Щоб довести це, потрібно простежити за користувачем, а точніше за його поглядом. Саме для цього і створена технологія айтрекінгу. Вона дозволяє відстежити, на яких елементах сайту користувач фіксує погляд, а які просто не помічає [6].

Для цього використовується нове надчутливе обладнання: пристрої, оснащені камерами та інфрачервоними датчиками для реєстрації погляду людини на об'єкті. Як результат замовник дослідження отримує звіт, що складається $з$ двох частин: графічної та аналітичної.

Графічна частина звіту складається з трьох макетів:

1. Sight pass - карта траєкторії руху очей і точок фіксації погляду респондента. Траєкторії перегляду дозволяють досліднику побачити в якій послідовності респондент звертає увагу на елементи, що його цікавлять, а також побачити точки фіксації (місця, які учасники переглядають від 100 до 500 мс) та саккади (стрибкоподібні рухи погляду) - місця, де респондент монотонно переглядає. Траєкторії на карті позначаються лініями, а точки фіксації - кружечками, чим вони більші, тим більше часу витрачав респондент на фокусування.

2. Heat maps - теплові карти уваги, що відображають ступінь концентрації уваги на тій чи іншій частині сайту. На карті точки фіксації кожного респондента накладаються і утворюють певні зони, де більш червоні кольори демонструють більший ступінь фіксації, жовтий - середній, зелений - низький, а відсутність теплової зони - відсутність фіксацій погляду респондента.

3. Areas of interest (AOI) - зони інтересу з процентним значенням частки фіксацій на конкретній області веб-сторінки і середньою тривалістю на кожній окремій області. Так, замовник може наглядно побачити, що, якщо його заклик до дії або саме повідомлення знаходиться у зоні інтересу лише 10 відсотків відвідувачів сайту, то переміщення об'єкту у більш цікаву зону для відвідувачів, може збільшити ймовірність реакції на об’єкт [4].

Аналітична частина пропонує розгорнутий аналіз поведінки користувача на сайті, а також експертні рекомендації про те, що необхідно змінити на сайті для поліпшення користувацького досвіду, підвищення конверсії. Слід зазначити, що для якісної інтерпретації результатів айтрекінг досліджень необхідний спеціаліст, що має високий рівень кваліфікації в області не тільки маркетингу та IT-технологій, а й психофізики зорових процесів, крім того, пропонується використовувати спеціальні програми для обробки даних, наприклад, IBM Watson Analytics та Tobii Technology, що дозволить легко знаходити зв'язок між різними змінними. 
Айтрекінг видає наступні показники:

- час до першої фіксації (time to first fixation) - час в секундах від того моменту, коли стимул був показаний до моменту, коли він потрапить у зону інтересів респондента;

- кількість фіксацій не в рамках зони, яка досліджується (fixations before) кількість фіксацій до того, як респондент опиниться у рамках АOI;

- тривалість фіксації (fixation length) - тривалість фіксації в секундах в межах AOI;

- кількість фіксацій (fixation count) - кількість фіксацій за весь період перегляду чи за одну секунду в рамках $\mathrm{AOI}$;

- тривалість спостереження (observation length) - загальний час в секундах, коли респондент перебував у зоні інтересів, починаючи 3 фіксацієї всередині зони і закінчуючи фіксацією за ії межами;

- кількість спостережень (observation count) - кількість відвідувань однакових АOІ;

- відсоток респондентів, що фіксували свій погляд принаймні один раз на об'єкті дослідження і він входив у їх зону інтересів (participant \%);

- швидкість переміщення погляду (path velocity) - тривалість всіх відрізків між послідовними фіксаціями, що розділена на загальний час в секундах [3]. Показник вимірюється в пікселях в секунду. Слід зауважити, що значення швидкості, звичайно, пов'язано з розміром монітора, відстанню між ним і очима, частотою айтрекера та ін.

Для наочності, зобразимо деякі аналітичні показники на рисунку.

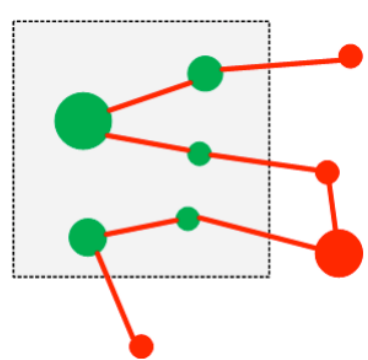

(a)

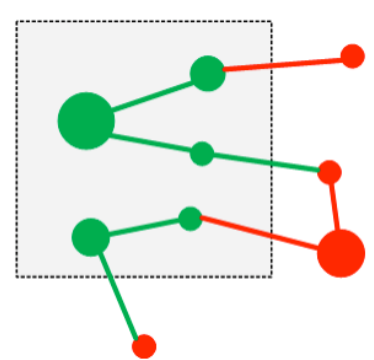

(б)

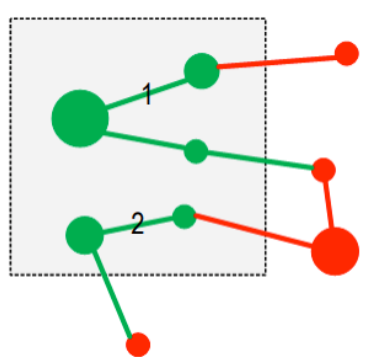

(в)

Рисунок - Схематичне зображення аналітичних показників: (а) - кількість фіксацій; (б) - тривалість спостереження; (в) - кількість спостережень. Побудовано авторами на основі [3]

Варто зазначити, що показники при тестуванні веб-сайтів за допомогою айтрекінгу необхідно розглядати у взаємозв'язку та зіставлені з критеріями оцінки інтернет комунікацій. Науковці виділяють три критерії за якими має відбуватися оцінювання ефективності комунікацій: target (цільова аудиторія), speed (швидкість), cost (вартість) [2]. 
В рамках критерію «Вартість» розглядаються показники Key Performance Indicators (КРI). У таблиці спробуємо зіставити показники айтрекінгу 3 показниками, які підлягають виміру у процесі визначення КPI Інтернеткомунікацій.

Таблиця - Зіставлення показників ефективності Інтернет-комунікацій та показників айтрекінгу (побудовано авторами на основі [2])

\begin{tabular}{|c|c|c|}
\hline $\begin{array}{c}\text { Показники } \\
\text { ефективності } \\
\text { Інтернет-комунікацій }\end{array}$ & Показники айтрекінгу & Пояснення \\
\hline $\begin{array}{l}\text { Кількість замовлень } \\
\text { за вибраний період }\end{array}$ & $\begin{array}{ll}\text { - } & \text { кількість фіксацій } \\
\text { - } & \text { тривалість фіксацій } \\
\text { - } & \text { тривалість } \\
& \text { спостереження } \\
\text { - } & \text { кількість спостережень } \\
\text { - } & \text { відсоток респондентів, } \\
& \text { що фіксували погляд }\end{array}$ & $\begin{array}{l}\text { Отримані результати після айтрекінгу } \\
\text { можуть слугувати прогнозом для } \\
\text { визначення потенційного обсягу } \\
\text { замовлень }\end{array}$ \\
\hline $\begin{array}{l}\text { Кількість повторних } \\
\text { замовлень }\end{array}$ & - кількість спостережень & $\begin{array}{l}\text { Дозволить оцінити наскільки сайт } \\
\text { цікавий для цільової аудиторії }\end{array}$ \\
\hline $\begin{array}{l}\text { Кількість активних } \\
\text { дій та кліків }\end{array}$ & $\begin{array}{ll}- & \text { тривалість фіксації } \\
\text { - } & \text { тривалість } \\
& \text { спостереження } \\
\text { - } & \text { швидкість перегляду } \\
\text { - } & \text { відсоток респондентів }\end{array}$ & $\begin{array}{l}\text { Отримані показники не можуть } \\
\text { оцінити «кількість», але можуть } \\
\text { продемонструвати зони, на які } \\
\text { достатньою ймовірністю були б } \\
\text { здійсненні переходи }\end{array}$ \\
\hline $\begin{array}{l}\text { Час перебування на } \\
\text { сайті }\end{array}$ & $\begin{array}{ll}\text { - } & \text { час до першої фіксації } \\
\text { - } & \text { тривалість фіксації } \\
\text { - } & \text { тривалість } \\
& \text { спостереження }\end{array}$ & $\begin{array}{lr}\text { Визначення за допомогою } & \text { айтрекера } \\
\text { «слабких } & \text { місць» } \\
\text { продемонструвати } & \text { поже } \\
\text { відповідного значення } & \text { показника } \\
\text { часу перебування на сайті } & \\
\end{array}$ \\
\hline Показник відмов & 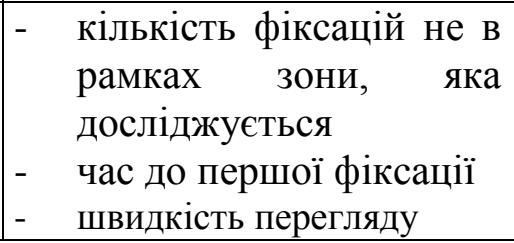 & 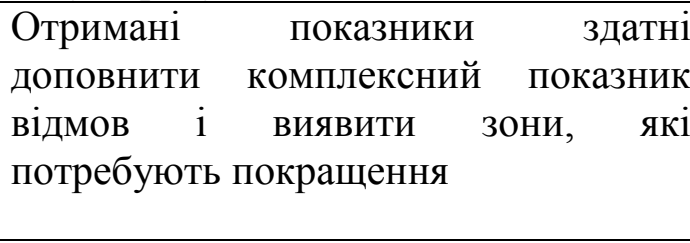 \\
\hline
\end{tabular}

Показники ефективності Інтернет-комунікацій, що зазначені у таблиці це не повний перелік змінних, яких торкаються рекомендації та висновки айтрекінгу. За допомогою комплексного звіту дослідження можна корегувати не тільки показник глибини перегляду, a i конверсії, що $\epsilon$ одним 3 найважливіших показників Інтернет-комунікацій.

Критерій оцінки ефективності маркетингових Інтернет-комунікацій: «Цільова аудиторія» може бути досліджений при проведені дослідження айтрекером. Так, існує можливість вибору респондентів за раніше сформованими гіпотезами і перевірка їх залученості у процесі дослідження. 
Айтрекінг допомагає відстежувати і оцінювати якість таргетування і цільової аудиторії.

Що стосується критерію «Швидкість», то цей критерій зазнає глибокої оцінки за допомогою методу айтрекінгу, так як він здатен не тільки виміряти час і відповідно швидкість переміщення погляду по структурі сайту, а й виявити його «слабкі місця», реорганізація яких допоможе підвищити показники критерія.

Висновки. У процесі дослідження було комплексно розглянуто поняття нейромаркетингу та його інструментів дослідження. Технологія, що передбачає застосування одного 3 інструментів нейромаркетингу - айтрекінг, була детально проаналізована. У ході аналізу визначено, що результати дослідження за допомогою айтрекера містять як показники, так і візуальні карти, що допомагає більш чітко відповісти на питання дослідження та сформувати рекомендації. Важливою частиною дослідження стало зіставлення отриманих аналітичних показників айтрекінгу 3 критеріями оцінки ефективності маркетингових Інтернет-комунікацій, що доводить актуальність використання айтрекінгу при тестуванні веб-сторінок. Подальше дослідження нейромаркетингу та глибинний аналіз його інструментів стануть темами наступних досліджень.

\section{Література:}

1. Вудвуд В. В. Нейромаркетинг - новітній інфструмент впливу на поведінку споживачів у недосконалих умовах ринкової економіки України / В. В. Вудвуд, А. Я. Білоус // Інноваційна економіка. - 2013. - № 7. - С. 210-212.

2. Зозульов О. В. Підходи до оцінювання ефективності маркетингових Інтернет-комунікацій / Є. А. Домашева, О. В. Зозульов. // Економічний вісник НТУУ "КПІ". - 2017. - №14.

3. 7 Most Used Eye Tracking Metrics and Terms [Electronic resource] // Imotions. - 2015. Resource access mode: https://imotions.com/blog/7-terms-metrics-eye-tracking/.

4. Ай-трекинг для оценки пользовательского опыта [Електронний pecypc] // GetGoodRank Режим доступу до ресурсу: http://blog.getgoodrank.ru/eye-tracking-dlya-ocenki-polzovatelskogoopyta/.

5. Кан Е.Я. Нейромаркетинг - механизм манипулирования потребителями [Електронний ресурс] / Е.Я. Кан. - Режим доступу до ресурсу: https://scholar.google.com/citations?user=hfnv5uUAAAAJ\&hl=ru.

6. Следи за взглядом, или технология айтрекинга увеличивает продажи [Електронний ресурс] // Demis group - Режим доступу до pecypcy: http://www.demis.ru/articles/eye-tracking.

7. NeuroLab Hardware [Електронний pecypc] // CoolTool. - 2017. - Режим доступу до pecypсу: https://cooltool.com/neurolab. 